\title{
EFEKTIVITAS PENGGUNAAN OBAT KUMUR BERALKOHOL DAN NON-ALKOHOL TERHADAP PENURUNAN INDEKS PLAK MAHASISWA D-IV JURUSAN KEPERAWATANGIGI POLTEKKES MAKASSAR
}

\author{
Asridiana, Ernie Thioritz
}

\begin{abstract}
ABSTRAK
Kesehatan gigi dan mulut masyarakat Indonesia masih merupakan hal yang perlu mendapatkan perhatian serius dari tenaga kesehatan, baik dokter maupun perawat gigi. Berdasarkan Riset Kesehatan Dasar (Riskesdas) nasional 2013, prevalensi nasional masalah kesehatan gigi dan mulut mencapai 25,9\% dan sebanyak 14 provinsi di Indonesia, memiliki prevalensi masalah gigi dan mulut di atas prevalensi nasional. Obat kumur umumnya adalah cairan antiseptic yang digunakan untuk membersihkan sela-sela gigi, permukaan lidah dan gusi, serta mulut bagian belakang atau kerongkongan. Fungsi obat kumur untuk mengurangi bau mulut serta menjaga mulut tetap lembab dan menetralkan asam. Obat kumur merupakan salah satu media kontrol plak yang mudah didapat dan praktis untuk digunakan. Jenis penelitian yang digunakan dalam penelitian ini adalah experimental murni. Desain penelitian yang digunakan dalam penelitian ini adalah pretest post test group design. Metode pengambilan sampel yang digunakan adalah Quota sampling terhadap Mahasiswa D-IV Jurusan Keperawatan Gigi. Data diuji dengan menggunakan uji t data berpasangan untuk membandingkan dua rata-rata sebelum dan sesudah perlakuan pada obat kumur yang mengandung alkohol dan non alkohol, analisis varians desain acak sempurna untuk menentukan penurunan indeks terbesar dan uji $t$ independent untuk membandingkan obat kumur yang mengandung alkohol dan non alkohol. Obat kumur beralkohol lebih efektif menurunkan indeks plak dari pada obat kumur non-alkohol.
\end{abstract}

Kata Kunci: Obat Kumur, Indeks Plak, Alkohol dan Non-Alkohol

PENDAHULUAN

Kesehatan gigi dan mulut masyarakat Indonesia masih merupakan hal yang perlu mendapatkan perhatian serius dari tenaga kesehatan, baik dokter maupun perawat gigi. Berdasarkan Riset Kesehtan Dasar (Riskesdas) nasional 2013, prevalensi nasional masalah kesehatan gigi dan mulut mencapai $25,9 \%$ dan sebanyak 14 provensi di indonesia, memiliki prevalensi masalah gigi dan mulut diatas prevalensi nasional dan untuk profinsi sulawesi utara mencapai 31,6\% bermasalah gigi dan mulut. (Riskesdas, 2013)

Faktor umum yang menyebabkan terjadinya penyakit gigi dan mulut ialah lapisan tipis yang dinamakan plak gigi. Plak adalah suatu lapisan lengket yang merupakan kumpulan dari bakteri. Plak ini akan mengubah karbohidrat atau gula yang berasal dari makanan kamu menjadi asam cukup kuat untuk merusak gigi. (Rahmadhan, 2010)
Plak yang tidak dibersihkan secara teratur akan mengalami pematangan sehingga membentuk karang gigi dan bersifat keras dan hanya biasa dibersihkan dengan alat khusus. (Veld HI, 2008)

Bakteri yang melekat pada gigi mengakitabatkan terjadinya plak dan plak yang tidak bersih akan meningkatkan kerentanan terhadap karies infeksi periodontal. Plak yang tidak dibersihkan akan menyebabkan Oral Hygiene buruk yang dapat menimbulkan berbagai resiko penyakit mulut. (Hiranya, 2010)

Kontrol plak sehari-hari umumnya dilakukan dengan cara mekanis melalui penyikatan gigi, pembersihan interdental dengan benang gigi (flossing) dan penggunaan obat kumur sebagai tambahan dalam penyingkiran plak. (Felton, 2007)

Obat kumur umumnya adalah cairan antiseptic yang digunakan untuk 
membersihkan sela-sela gigi, permukaan lidah dan gusi, serta mulut bagian belakang atau kerongkongan. Fungsi obat kumur untuk mengurangi bau mulut serta menjaga mulut tetap lembab dan menetralkan asam. Obat kumur merupakan salah satu media kontrol plak yang mudah didapat dan praktis untuk digunakan. Obat kumur menjadi kebutuhan bagi semua orang karena diyakini dapat mencegah pembentukan plak gigi dan gingivitis baik secara mekanik maupun khemis. Berkumur dengan obat kumur yang juga dapat mencapai lebih banyak permukaan gigi dan rongga mulut. Obat kumur yang beredar di masyarakat secara komersial terdiri dari obat kumur beralkohol dan yang tidak mengandung alkohol. Masingmasing memiliki kelebihan maupun kekurangan. (Samuels, 2012)

Saat ini kesadaran masyarakat mengenai manfaat dan cara pemakaian obat kumur masih sangat kurang, terlebih jika penggunaan obat kumur mengandung alkohol. Dalam kehidupan sehari-hari kita lebih banyak menggunakan obat kumur yang mengandung alkohol dan tidak peduli dengan efek samping dari alkohol tersebut. Penggunaan obat kumur yang mengandung alkohol dalam jangka panjang dapat menyebabkan mulut kering, mengurangi produksi air liur yang akan memengaruhi bau mulut dan menyebabkan seseorang menjadi lebih beresikoterkena kerusakan gigi. Oleh sebab itu diproduksi obat kumur non alkohol untuk meminimalisir efek samping yang akan terjadi dan dapat digunakan dalam jangka panjang. (McCullough, 2008)

Pada hasil penelitian yang dilakukan oleh Marcella talumewo, dkk 2015, di Universitas samratulangi, Manado angkatan 2011 menunjukkan bahwa terdapat perbedaan efektifitas obat kumur beralkohol nan non alkohol dalam menurunkan akumulasi plak, hasil menunjukkan bahwa obat kumur beralkohol lebih efektif dibandingkan yang non alkohol.

Berdasarkan data di atas peneliti tertarik untuk melakukan penelitian terhadap Mahasiswa Keperawatan Gigi karena tingkat pengetahuan tentang kesehatan gigi dan mulut masih rendah.

\section{METODE PENELITIAN}

Jenis penelitian yang digunakan dalam penelitian ini adalah experimental murni. Desain penelitian yang digunakan dalam penelitian ini adalah pretest post test group design. Metode pengambilan sampel yang digunakan adalah Quota sampling terhadap Mahasiswa D-IV Jurusan Keperawatan Gigi. Penelitian ini dilakukan di Kampus Keperawatan Gigi Poltekkes Kemenkes Makassar. Penelitian ini dilakukan pada awal bulan Oktober. Populasi penelitian ini yaitu Mahasiswa D-IV Jurusan Keperawatan Gigi berjumlah 406 mahasiswa. Sampel yang digunakan dalam penelitian ini sebanyak 30 sampel.

Dalam penelitian ini menerapkan kriteria inklusi yaitu sampel harus dalam keadaan fit dan sehat, serta tidak makan selama 1 jam sebelum penelitian. Hal ini bertujuan untuk mengkondisikan mulut dalam keadaan senormal mungkin dengan berbagai fluor alami di dalam mulut, agar penelitian murni yang diteliti yaitu plak bukan sisa makanan yang didapatkan.

Data yang dikumpulkan adalah data primer dalah data yang diperoleh dari observasi secara langsung melalui penelitian, dan data sekunder berupa daftar kehadiran Mahasiswa. Penyajian data dalam bentuk 
analisis data yang digunakan adalah SPSS mengenai hasil penelitian, kemudian mendistribusikannya dalam bentuk tabel. Data diuji dengan menggunakan uji $t$ data berpasangan untuk membandingkan dua rata-rata sebelum dan sesudah perlakuan pada obat kumur yang mengandung alkohol dan non alkohol, analisis varians desain acak sempurna untuk menentukan penurunan indeks terbesar dan uji $t$ independent untuk membandingkan obat kumur yang mengandung alkohol dan non alkohol.

Pemeriksaan awal dilakukan pada kedua kelompok sebelum berkumur, mahasiswa masing-masing kelompok terlebih dahulu diberikan larutan disclosing kemudian diperiksa indeks plak giginya. Menyikat gigi secara manual, setelah itu menunggu selama 1 jam, diberikan obat kumur sesuai kelompok masing-masing. Kelompok $A$ berkumur dengan obat kumur beralkohol dan kelompom $B$ berkumur dengan obat kumur non- alkohol sebanyak $20 \mathrm{ml}$ selama 30 detik. Cairan dibuang dan dilakukan pemeriksaan plak setelah perlakuan mengguakan sode dan disclosing. Hasil pemeriksaan indeks plak dicatat dan diolah dalam bentuk tabel menggunakan computer, data disajikan dalam bentuk tabel.

\section{HASIL PENELITIAN}

Tabel 1. Distribusi Responden Berdasarkan Jenis Kelamin Yang Diperiksa Indeks Plak

\begin{tabular}{|c|c|c|}
\hline Jenis Kelamin & $\mathbf{N}$ & $\%$ \\
\hline Perempuan & 24 & $80 \%$ \\
\hline Laki-laki & 6 & $20 \%$ \\
\hline Total & 30 & $\mathbf{1 0 0} \%$ \\
\hline
\end{tabular}


Data pada tabel 1 berdasarkan jenis kelamin yang diperiksa indeks plaknya perempuan berjumlah 24 orang dengan persentase $80 \%$ dan laki-laki 6 orang dengan persentase $20 \%$ dari total sampel 30 orang pada pemeriksaan indeks plak.

Tabel 2 Distribusi Responden Berdasarkan Usia Yang Menggunakan Obat kumur Beralkohol

\begin{tabular}{|c|c|c|}
\hline Usia (Tahun) & $\mathbf{N}$ & $\%$ \\
\hline 19 & 6 & $40 \%$ \\
\hline 20 & 5 & $34 \%$ \\
\hline 21 & 4 & $26 \%$ \\
\hline
\end{tabular}

Data pada tabel 2 berdasarkan usia yang menggunakan obat kumur beralkohol menunjukkan pada usia 19 tahun berjumlah 6 dengan persentase $40 \%$ sedangkan yang berusia 20 tahun terdapat 5 orang dengan persentase $34 \%$ dan untuk usia 21 berjumlah 4 orang dengan persentase $26 \%$.

Tabel 3. Distribusi Responden Berdasarkan Usia Yang Mengguanakan

Obat Kumur Non-Alkohol

\begin{tabular}{|c|c|c|}
\hline Usia (Tahun) & N & $\%$ \\
\hline 19 & 5 & $33,30 \%$ \\
\hline 20 & 5 & $33,30 \%$ \\
\hline 21 & 5 & $33,30 \%$ \\
\hline Total & 15 & $99,90 \%$ \\
\hline
\end{tabular}

Data tabel 3 terdapat 5 orang yang berumur 19 tahun $(33,30 \%)$ sedangkan pada umur 20 tahun terdapat 5 orang $(33,30 \%)$ dan pada umur 21 terdapat 5 (33,30\%) dari total 15 orang sampel.

Tabel 4. Distribusi Responden Indeks Plak Sebelum Dan Sesudah menggunakan obat kumur beralkohol dan non-alkohol

\begin{tabular}{|l|c|c|c|c|c|}
\hline \multirow{2}{*}{ Jenis Obat Kumur } & \multirow{2}{*}{$\mathrm{N}$} & \multicolumn{4}{|c|}{ Indeks Plak } \\
\cline { 3 - 6 } & & Sebelum & $\%$ & Sesudah & $\%$ \\
\hline Beralkohol & 15 & 30,7 & 2,04 & 9,9 & 0,66 \\
\hline Non-Alkohol & 15 & 29,2 & 1,94 & 11,4 & 0,76 \\
\hline Total & 30 & 59,9 & 3,98 & 21,3 & 1,42 \\
\hline
\end{tabular}




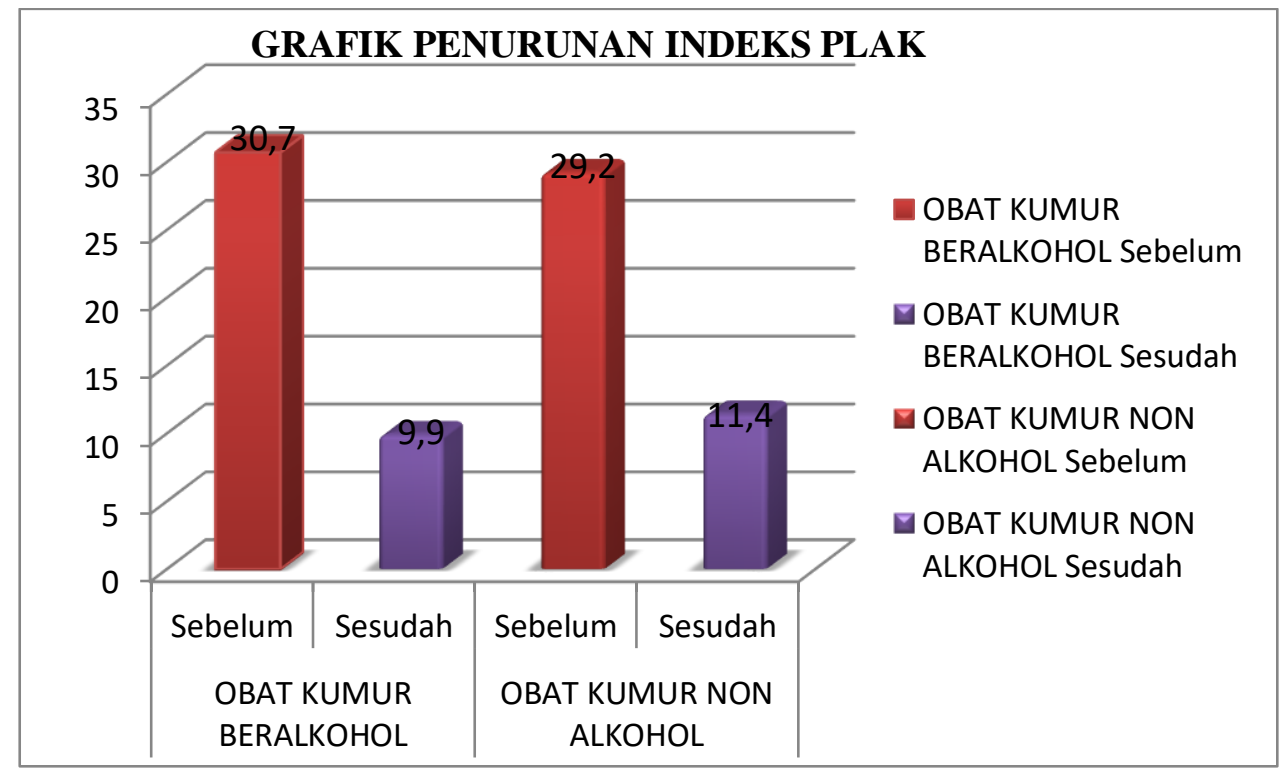

Tabel 4. berdasarkan tabel diatas sebelum menggunakan obat kumur beralkohol indeks plak 30,7 (2,04), setelah menggunakan obat kumur beralkohol indeks plak 9,9 (0,66\%), sedangkan sebelum menggunakan obat kumur non-alkohol 29,2 $(1,94 \%)$ dan setelah menggunakan obat kumur non alkohol 11,4 (0,76\%).
Berdasarkan grafik diatas dapat dijelaskan bahwa sebelum berkumur obat kumur beralkohol 30,7 dan setelah berkumur obat kumur alkohol 9,9 sedangkan sebelum berkumur obat kumur non alkohol 29,9 dan setelah berkumur obat kumur non alkohol 11,4 .

Tabel 5. Responden Reratan Indeks plak Gigi Sebelum Dan Sesudah menggunakan Obat Kumur Beralkohol dan Non-Alkohol

\begin{tabular}{|c|c|c|c|}
\hline \multirow{2}{*}{ Jenis Obat Kumur } & Indeks Plak & Indeks Plak & \multirow{2}{*}{ P } \\
\cline { 2 - 3 } & Sebelum perlakuan & $\begin{array}{c}\text { Sesudah } \\
\text { perlakuan }\end{array}$ & \\
\hline Obat kumur beralkohol & 2,04 & 0,66 & $<0,000$ \\
\hline Obat kumur non alkohol & 1,94 & 0,76 & $<0,000$ \\
\hline
\end{tabular}

Tabel 5, indeks plak sebelum menggunakan obat kumur berlkohol berjumlah 2,04 dan indeks plak sesudah menggunakan obat kumur beralkohol berjumlah 0,66, sedangkan sebelum mengunakan obat kumur non-alkohol indeks plak berjumlah 1,94 dan setelah berkumur dengan obat kumur non alkohol indeks. 


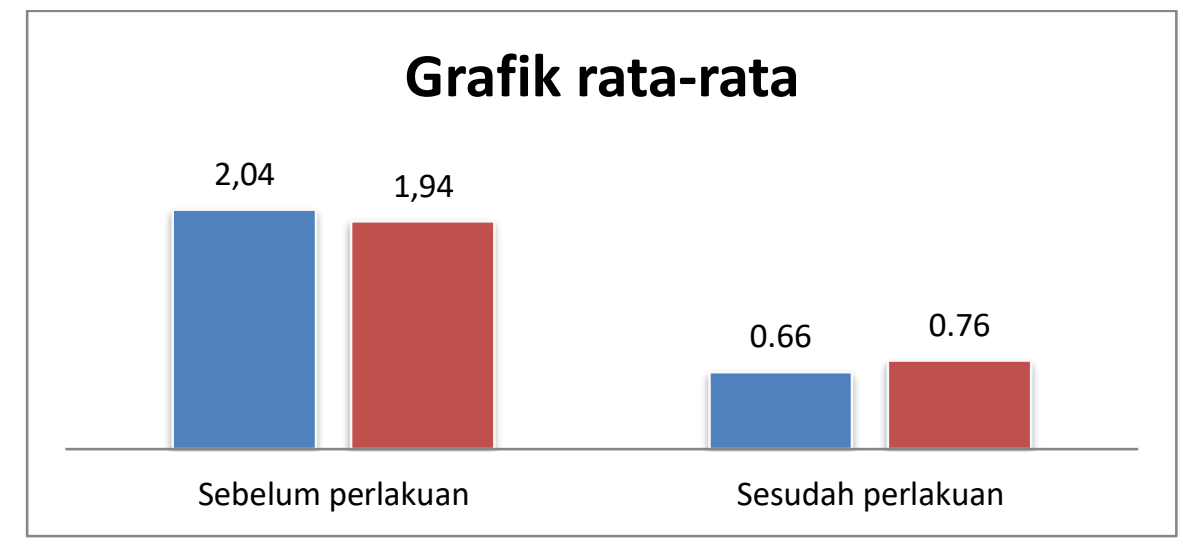

Berdasarkan grafik diatas dapat dijelakan bahwa rata-rata skor indeks plak gigi yang diperoleh sebelum perlakuan yakni kategori perlakuan obat kumur beralkohol sbesar ,04 dan pada perlakuan obat kumur

\section{PEMBAHASAN}

Penelitian ini dilakukan pada bulan Oktober tahun 2018 di Poltekkes Kemenkes Makassar Jurusan Keperawatan Gigi, pemeriksaan meliputi indeks plak gigi sebelum dan setelah berkumur dengan obat kumur beralkoho dan non alkohol. sebelum penggunaan obat kumur beralkohol terdapat rata-rata indeks plak pada kedua kelompok tidak menunjukkan perbedaan yang signifikan yaitu obat kumur beralkohol 2,04 dan non alkohol 1,94. Namun setelah menggunakan obat kumur non alkohol terlohat perbedaan antara kedua obat kumur yaitu 0,66 untuk obat kumur beralkohol dan 0,76 untuk obat kumur non alkohol.

Perubahan dari hasil penilaian indeks plak sebelum dan sesudah berkumur dengan obat kumur beralkohol dan non alkohol disebabkan karena dalam obat kumur yang beralkohol mengandung alkohol, Sorbitol, Flavor, Poloxamer 407, Bezoic acid, Khlorheksidin, Methyl Salicylate, Hexetidine, Menthol, sodium, Floraide, Sucralose. non-alkohol sebesar 1,94 adapun skor ratarata indeks plak gigi setelah perlakuan obat kumur beralkohol menjadi 0,66 perlakuan obat kumur non alkohol menjadi 0,76 .

Dimana alkohol pada obat kumur dapat mengganggu aktivitas sel pada bakteri sehingga terbentuk ikatan yang lemah dan segera mengalami penguraian, kemuadia membrane sel pada bakteri terlepas sehingga bakteri pada rongga mulut mati atau terlepas.

Fungsi alkohol pada obat kumur sebagai pelarut bahan aktif, sebagai pengawet dan sebagai amtiplak membunuh bakteri pada rongga mulut sehingga dapat mencegah tumbuhnya plak yang berlebihan.

Berdasarkan penelitan klinis yang dilakukan oleh Leyes Borrajo di Spanyol mengenai efektivitas obat kumur berbahan aktif khlorhekssidin dengan alkohol atau non alkohol aktivitas dalam mengurangi jumlah koloni bakteri rongga mulut. Ada perbedaan penurunan jumlah bakteri antara kedua grup tersebut, dan yang lebih efektif ialah obat kumur khlorheksidin beralkohol, dengan hasil obat kumur khlorheksidin beralkohol 0,78 dan untuk obat kumur khlorheksidin tanpa alkohol 0,97 . 
Kontraksi alkohol yang dignakan dalam obat kumur dari konsentrasi optimum $50 \%$ sampai $70 \%$ sehingga dapat memberikan efek antiseptic, maka selain fungsinya pelarut, alkohol dalam obat kumur tidak memberikan aksi terapeutik. Alkohol dan obat kumur hanya berefek lokal dan metabolisme, sebagaimana halnya dalam minuman (Toedt J, 2005).

Hexetidine merupakan antibakteri dengan spectrum luas dengan konsentrasi rendah bermanfaat untuk mikroorganisme rongga mulut, hexetidine dapat digunakan pada penderita dengan radang tenggorokan mulut dan nasopharyn pernyataan ini dibuktikan pada pencobaan dengan larutan $0,1 \%$ hexetidin sebagai obat kumur pada orang-orang amerika yang menderita rongga mulut ternyata radang dapat sembuh dengan baik. Hal ini berarti hexetidine akan bermanfaat untuk penderita dengan kelainan periodontal yang disebabkan oleh mikroorganisme.

Penelitian ini membuktikan bahwa hexetidine dapat mengikat protein mukosa mulut sehingga dapat menguntungkan hexetidine sebagai antibakteri pendapat ini diperkuat oleh bourgonet yang mengatakan bahwa hexetidine dapat memperpanjang efek anti bakteri karena adanya ikatan dengan protein mikosa.

Dalam penelitian ini menerapkan kriteria inklusi yaitu sampel harus dalam keadaan fit dan sehat, serta tidak makan selama 1 jam sebelum penelitian. Hal ini bertujuan untuk mengkondisikan mulut dalam keadaan senormal mungkin dengan berbagai flor alami di dalam mulut, agar penelitian murni yang diteliti yaitu plak bukan sisa makanan atau berbagai biasa yang didapatkan. Dari hasil uji independent t-test menyatakan ada perbedaan yang bermakna menggunakan obat kumur beralkohol dan non alkohol dalam menurunkan indeks plak.

Dua perbedaan nyata dari kedua perlakuan menggunakan obat kumur, yaitu ada keberadaan alkohol yang digunakan pada obat kumur yang dipakai. Alkohol pada obat kumur antiseptic yaitu menggunakan aktifitas sel pada bakteri sehingga terbentuk ikatan yang lemah dan segera mengalami pengurangan, kemudian membrane sel pada bakteri terlepas sehingga bakteri pada rongga mlut akan terlepas.

Alkohol dalam membunuh bakteri adalah dengan cara denaturasi dan koagulasi protein sel bakteri. Senyawa alkohol dapat menimbulkan denaturasi protein sel bakteri dan proses tersebut memerlukan air. Hal ini ditunjukan oleh fakta bahwa alkohol absolute, yang tidak mengandung air, mempunyai aktivitas anti bakteri jauh lebih rendah dibanding alkohol yang mengandung air. Selain itu turunan alkohol juga menghambat system fosforilasi dan efeknya terlihat jelas pada mitokondria yaitu hubungan substartnikotinamid adenine nukleotida (NAD).

\section{Kesimpulan}

Obat kumur beralkohol lebih efektif dibanding obat kumur non alkohol. Obat kumur beralkohol lebih efektif menurunkan indeks plak dari pada obat kumur non-alkohol.

\section{Saran}

Agar menggunakan obat kumur hexadol beralkohol untuk menurunkan jumlah bakteri yang berlebihan didalam mulut. Selain itu, Perlu dilakukan penelitian lebih lanjut dengan menggunakan dosis alkohol yang lebih bervariasi sehingga dapat diketahui dosis yang paling tepat dan efek dari alkohol 
untuk digunakan didalam obat kumur mengurangi jumlah bakteri rogga mulut.

Selain penelitian lanjutan, juga perlu dilakukan penelitian lebih lanjut dengan menggunakan bahan lain, misalnya, saliva atau kerokan lidah agar dapat dijadikan bahan perbandingan.

\section{DAFTAR PUSTAKA}

1. Badan Penelitian dan Pengembangan Kesehatan Departemen Kesehatan RI Laporan Hasil Riset Kesehatan Dasar (Riskesdas) Nasional, Jakarta;2013.

2. Rahmadhan, Ardyan Gilang. Serba Serbi Kesehatan Gigi dan Mulut. Jakarta: Bukune, 2010.
3. Veld HI. Ilmu kedokteran gigi pencegah. Sutatmi Suryo. Yogyakarta: Universitas Gadjah mada; 2008.

4. Hiranya Putri Megananda, Eliza Herijulianti, Neneng Nurjannah. IImu Pencegahan Penyakit Jaringan Keras dan Jaringan Pendukung gigi. Jakarta: EGC. 2010

5. Felton, Champan and Felton. Basic Guide to oral health education and promotion, wiley-black A John Wiley \& Sons, Ltd., Publication; 2007

6. Samuels N, Grbic J.T, saffer A.J, Wexler I.D, and Williams R.C. preventing an herbal model; a pilot study. Compend Contic Educ Dent. 2012

7. McCullough M J, Farah C S. The role of alcohol in oral carcinogenesis with particular reference to alkohol containing mouthwashes. Aust Dent J. 2008 